J. Dairy Sci. 95:1586-1586

http://dx.doi.org/10.3168/jds.2012-95-3-1586

(C) American Dairy Science Association ${ }^{\circledR}, 2012$.

\title{
Erratum to "Technical note: Validation of an ELISA for measurement of tumor necrosis factor alpha in bovine plasma" (J. Dairy Sci. 94:3504-3509)
}

\section{J. K. Farney, L. K. Mamedova, B. H. Godsey, and B. J. Bradford}

There was an oversight in the protocol described in this paper. The final protocol outlined in paragraph 2 of the right column on page 3505 refers to a reagent diluent that is not defined. This reagent diluent is $4 \%$ bovine serum albumin in PBS ( $\mathrm{pH} 7.5)$. The authors apologize for this omission.

\section{REFERENCES}

Farney, J. K., L. K. Mamedova, B. H. Godsey, and B. J. Bradford. 2011. Technical note: Validation of an ELISA for measurement of tumor necrosis factor alpha in bovine plasma. J. Dairy Sci. 94(7):3504-3509. 